\title{
Diffuse Large B-Cell Lymphoma in Complete Remission
}

National Cancer Institute

\section{Source}

National Cancer Institute. Diffuse Large B-Cell Lymphoma in Complete Remission. NCI

Thesaurus. Code C159239.

History of diffuse large B-cell lymphoma with no evidence of disease after therapy. 